\title{
Alveolar Type II Epithelial Cells Produce Interleukin-6 In Vitro and In Vivo Regulation by Alveolar Macrophage Secretory Products
}

\author{
Bruno Crestani, * Pascale Cornillet, ${ }^{*}$ Monique Dehoux, ${ }^{*}$ Corinne Rolland, * Moncef Guenounou, ${ }^{\star}$ and Michel Aubier * \\ *Institut National de la Santé et de la Recherche Médicale INSERM U 408 and ${ }^{8}$ Laboratoire de Biochimie A, Faculté Xavier Bichat, \\ Paris; and ${ }^{\ddagger}$ Laboratoire d'Hématologie, Hôpital Robert Debré, Reims, France
}

\begin{abstract}
The aims of this study were $(a)$ to determine if rat alveolar type II (ATII) cells and human pulmonary epithelial-derived cells (A549 cell line) could generate $\mathrm{IL-6}$ in vitro, (b) to characterize the cytokine regulation of $\mathrm{L}-6$ gene and protein expression in these cells, and (c) to detect the in vivo expression of immunoreactive IL-6 by human ATI cells. Rat ATII cells in primary culture secreted bioactive IL-6 and immunostained with an anti-IL-6 antiserum. Spontaneous IL-6 secretion by rat ATII cells amounted to $5,690 \pm 770 \mathrm{pg} / \mathrm{ml} / 10^{6}$ cells $(n=12)$ and was fivefold higher than spontaneous rat alveolar macrophages $\mathrm{IL}-6$ secretion $\left(1,052 \pm 286 \mathrm{pg} / \mathrm{ml} / 10^{6}\right.$ cells, $\left.n=8, P=0.001\right)$. Rat alveolar macrophage conditioned media (CM) increased IL-6 secretion by rat ATI cells through the effect of $\mathrm{LL}-1$ and TNF. IL-6 gene expression and IL-6 secretion by A549 cells was induced by $\mathrm{IL}-1 \beta$, TNF $\alpha$, and by human alveolar macrophages and THP1 cells CM. Induction was abolished when CM were preincubated with anti-IL-1 $\beta$ and anti-TNF $\alpha$ antibody. The combination of IFN $\gamma$ and LPS induced the expression of IL-6 mRNA by A549 cells whereas LPS alone had no effect. Immunohistochemical staining evidenced the expression of immunoreactive IL-6 by hyperplastic ATI cells in fibrotic human lung, a condition in which alveolar macrophages are known to be activated. ATII cells in normal human lung did not express immunoreactive IL-6.

Our findings demonstrate that ATII cells may be an important source of $\mathrm{IL-6}$ in the alveolar space thereby participating to the regulation of the intra-alveolar immune response. (J. Clin. Invest. 1994. 94:731-740.) Key words: alveolar macrophages • cytokines $\cdot$ lipopolysaccharide $\bullet$ pulmonary fibrosis • human lung
\end{abstract}

\section{Introduction}

Type II alveolar epithelial cells (ATII cells) ${ }^{1}$ have been shown to play a key role in the regulation of the alveolar space. ATII

Address correspondence to Prof. M. Aubier, Unité de Pneumologie, Hôpital Bichat, 46 rue Henri Huchard, 75018 Paris, France.

Received for publication 26 October 1993 and in revised form 1 April 1994.

1. Abbreviations used in this paper: AM, human alveolar macrophage; AM-CM, LPS-stimulated alveolar macrophage-conditioned media; ATII cells, type II alveolar cells; BAL, bronchoalveolar lavage; th, recombinant human; rm, recombinant murine; THP1-CM, LPS-stimulated THP1 cell-conditioned media.

J. Clin. Invest.

(C) The American Society for Clinical Investigation, Inc.

0021-9738/94/08/0731/10 \$2.00

Volume 94, August 1994, 731-740 cells synthesize and secrete surfactant, control the volume and composition of the epithelial lining fluid and proliferate and differentiate into type I alveolar epithelial cells after injury in order to maintain the integrity of the alveolar wall (1). Moreover, ATII cells are ideally located to have a role in modulating immunologic activity in the alveolar space. In this setting, both in vitro and in vivo data suggest that ATII cells could participate in the intra-alveolar cytokine network by secreting interleukin8 (IL-8) (2), interferon (3), monocyte chemoattractant protein1 (4), transforming growth factor-beta (5), platelet-derived growth factor $(6,7)$, and granulocyte monocyte colony-stimulating factor (8) under appropriate stimulation.

Interleukin-6 (IL-6) is a cytokine involved in the regulation of the immune response and inflammation. Also, $\mathrm{LL}-6$ modulates proliferation of lymphoid and nonlymphoid cells (9). IL-6 is produced mainly by monocytes (10) but numerous cell types such as fibroblasts (11), endothelial cells (12), and epithelial cells $(9,13)$ can also produce this cytokine. IL-6 is usually thought as a pro-inflammatory cytokine (10). However, it has been suggested that IL-6 may act as an inhibitor of local acute inflammation particularly in the lung (14).

Increased levels of IL-6 have been detected in the epithelial lining fluid recovered by bronchoalveolar lavage (BAL) in different pathologic conditions $(15,16)$. Although alveolar macrophages are certainly involved in vivo in the generation of alveolar IL-6 since they are known as potent producers of IL-6 (17), the possible contribution to IL-6 production by alveolar epithelial cells, particularly ATII cells, is unknown. Therefore this study was designed $(a)$ to determine if rat ATII cells and human pulmonary epithelial-derived cells (A549 cell line) could generate $I L-6$ in vitro, $(b)$ to characterize the cytokine regulation of IL-6 gene and protein expression in vitro, and $(c)$ to assess the in vivo expression of immunoreactive IL- 6 by ATII cells in human lung.

\section{Methods}

Reagents. Human recombinant (hr) interleukin-1beta (IL-1 $\beta$ ), tumor necrosis factor alpha (TNF $\alpha$ ), and IL-6, and murine recombinant ( $\mathrm{mr}$ ) IL-1 $\beta$ and TNF $\alpha$ were purchased from Immugenex (Los Angeles, CA). Human recombinant interferon gamma (IFN $\gamma$ ) was a generous gift of Roussel-Uclaf (Romainville, France). Rabbit anti-human TNF $\alpha$ antibody, anti-mouse TNF $\alpha$ antibody and goat anti-human IL- $1 \beta$ antibody (IgG fraction) were from Immugenex. Polyclonal rabbit anti-human IL6 antibody and rabbit anti-murine IL- $1 \alpha$ were obtained from Genzyme (Boston, MA). Phorbol 12-myristate 13-acetate (PMA) was obtained from Sigma Chemical Co. (La Verpilliere, France). Escherichia coli (strain 055: B5)-derived lipopolysaccharide (LPS) was obtained from Difco Laboratories (Detroit, MI).

Tissue culture media, supplements, and fetal bovine serum were obtained from Flow Labs (Irvine, U.K.) except of MEM non essential amino acids $(100 \times)$ and MEM vitamins $(100 \times)$ which were from GIBCO BRL Life Technologies (Cergy Pontoise, France). Tissue culture plasticware was from Costar Corp. (Cambridge, MA). 
Isolation of rat alveolar type II cells and preparation of rat alveolar macrophage conditioned medium. ATII cells were isolated from adult pathogen-free male Sprague-Dawley rats (Charles River Breeders, St Aubin les Elbeuf, France) by enzymatic dissociation and purified by differential adherence to plastic as previously described $(18) .10^{6}$ cells were plated in each well of a 24-well cell culture plate with $1 \mathrm{ml}$ of Dulbecco's modified Eagle's medium (DME) containing 10\% fetal bovine serum, $10^{5} \mathrm{U} / \mathrm{ml}$ penicillin, $100 \mathrm{mg} / 1$ streptomycin and $0.25 \mathrm{mg} /$ 1 amphotericin B (complete DME). After a 24-h period, nonadherent cells were removed by gently washing twice with PBS, fresh complete medium replaced and the cells were used for the experiments. ATII cells were routinely identified by the modified Papanicolaou stain and by phosphine fluorescence staining (19). $93 \pm 2 \%$ (mean \pm SEM, $n=12$ ) adherent cells were ATII cells $20 \mathrm{~h}$ after isolation. Adherent cell viability was higher than $98 \%$ as assessed by the trypan blue exclusion test. Contaminating cells consisted primarily of alveolar macrophages and fibroblasts.

To recover rat alveolar macrophages, the lungs of rats previously anesthetized with sodium pentobarbital and killed by exsanguination were lavaged ten times with $10 \mathrm{ml}$ sterile PBS. Lavage fluid was collected in 50-ml polypropylene tubes and centrifuged at $600 \mathrm{~g}$ for 10 $\mathrm{min}$. The cell pellet was resuspended in RPMI with $10 \%$ heat-inactivated fetal bovine serum, with antibiotics and glutamine, at a density of $10^{6}$ cells $/ \mathrm{ml} .10^{6}$ cells were plated in each well of a 24-well cell culture plate and allowed to adhere for $2 \mathrm{~h}$, then nonadherent cells were removed and fresh medium containing $10 \mu \mathrm{g} / \mathrm{ml}$ LPS was added. Adherent cells were more than $98 \%$ alveolar macrophages as assessed by non specific esterase stain (Sigma Chemical Co.). Conditioned media of LPS-activated rat AM (rat AM-CM) was recovered after a 24-h incubation period.

Culture of human A549 pulmonary epithelial cells and preparation of human alveolar macrophages conditioned media. To extend to the human the results obtained in the rat model, the A549 pulmonary epithelial cell line was obtained from the American Type Culture Collection (Rockville, MD). The A549 cell line, which is derived from a patient with alveolar cell carcinoma of the lung, has been used as a model of human ATII cells in the literature $(2,4,20,21)$. We used these cells in this study since human ATII cells are difficult to obtain in pure culture and are often contaminated with resident macrophages. A549 cells were grown to confluency on 100-mm petri dishes or on 24 dish cell culture plates in Ham F12 medium containing 15\% FBS, $4 \mathrm{mM}$ glutamine, $10^{5} \mathrm{U} /$ liter penicillin, $100 \mathrm{mg} /$ liter streptomycin, $0.25 \mathrm{mg} /$ liter amphotericin B, $1 \%(\mathrm{vol} / \mathrm{vol})$ MEM nonessential amino acids and $1 \%$ (vol/vol) MEM vitamin (complete Ham F12 medium).

The human alveolar macrophages were recovered from a normal nonsmoking volunteer who agreed to undergo flexible fiberoptic bronchoscopy with bronchoalveolar lavage by standard techniques (22). The subject was free of any respiratory or extra-respiratory disease at the time of examination and was not taking any medication. The recovered BAL fluid was filtered through sterile cotton gauze, then centrifuged at $600 \mathrm{~g}$. The cells were resuspended in RPMI 1640 containing $10 \%$ heatinactivated FBS, $2 \mathrm{mM}$ glutamine, $10^{5} \mathrm{U} /$ liter penicillin, $100 \mathrm{mg} /$ liter streptomycin, and plated on 24-dish cell culture plates at a concentration of $1 \times 10^{6}$ cells/dish. After a 2 -h incubation period at $37^{\circ} \mathrm{C}$ in a $5 \%$ $\mathrm{CO}_{2} / 95 \%$ air humidified incubator, nonadherent cells were removed by washing twice with complete media. The adherent cell population was $>98 \%$ AM as assessed by nonspecific esterase staining. LPS at a concentration of $10 \mu \mathrm{g} / \mathrm{ml}$ was added. Conditioned media of LPS-stimulated AM (human AM-CM) was recovered after a 24-h incubation period at $37^{\circ} \mathrm{C}$. Alternatively, conditioned media was prepared using THP1 cells (THP1-CM), a monocytic cell line, as previously described (22).

Determination of IL-6 concentration in cell culture supernatants. Bioactive IL-6 was measured in rat ATII cell and A549 cell culture supernatants using the IL-6 dependent B9 hybridoma cell line (23). B9 cells were cultured for $72 \mathrm{~h}$ in the presence of duplicate serial dilutions of cell supernatants in 96-well plates. B9 cell proliferation was estimated after $72 \mathrm{~h}$ of incubation using the MTT colorimetric assay (24). hrIL6 was used as an internal standard in all assays. One reference unit of
IL-6 was defined by the half-maximal proliferation of B9 cells. Immunoreactive IL-6 was measured in A549 cell supernatants using a commercially available IL-6 ELISA kit (EASIA; Medgenix, Fleurus, Belgium). This ELISA-kit consistently detected IL- 6 concentrations $>10 \mathrm{pg} / \mathrm{ml}$ in a linear fashion. Results are expressed as the mean of duplicate assays.

Northern blot analysis. Total cellular RNA from A549 cells grown in $100-\mathrm{mm}$ cell culture dishes and rat ATII cells grown in $25-\mathrm{cm}^{2}$ cell culture flasks was isolated using the guanidium thiocyanate method (25). RNA corresponding to $4.10^{6}$ cells $(\sim 20 \mu \mathrm{g})$ was size fractionated by electrophoresis through a $1 \%$ agarose gel containing $0.02 \mathrm{mM} \mathrm{L}-$ morpholinopropane sulfonic acid (Mops) buffer and $15 \%$ formaldehyde, then transferred to a nitrocellulose/nylon membranes (Amersham, Les Ulis, France), baked, prehybridized, and hybridized with a ${ }^{32}$ P-labeled plasmid cDNA probe. IL-6 RNA was detected using a 1.1-kb EcoRIBam HI fragment cDNA probe (26) (a generous gift of Dr Aggarwal, USA). Membranes were exposed for $15 \mathrm{~d}$ at $-80^{\circ} \mathrm{C}$ to Kodak X-OMAT XAR 5 films. Equivalent amounts of total RNA/gel were assessed by monitoring non specific hybridization with 18S rRNA. Autoradiographs were quantified using laser densitometry. The ratio of the IL-6 band density against the 18S rRNA band density was calculated for each lane in order to quantify the IL-6 mRNA according to the amount of total RNA/gel.

Stimulation of IL-6 secretion by rat ATII cell and A549 cell. Rat ATII cells were used $24 \mathrm{~h}$ after isolation. Cells were incubated with complete DME, and cytokines or rat AM-CM was added for the specific times and doses. Supernatants were recovered for bioactive IL-6 concentration determination. In these experiments, we stimulated rat ATII cells with murine recombinant cytokines since rat products were not available to us. These cytokines have been previously used for this purpose in the literature (27). In neutralizing studies, $\mathrm{CM}$ was pre-incubated overnight at $+4^{\circ} \mathrm{C}$ with constant agitation with rabbit anti-murine TNF $\alpha$ or anti-murine IL- $1 \alpha$ antibodies $(1 \mu \mathrm{g} / \mathrm{ml})$ or both.

On the day of use, A549 cells were washed twice with PBS and incubated with complete Ham F12 medium, and either cytokines, LPS, AM-, or THP1 cell conditioned media was added for the specific times and doses. Supernatants were recovered for bioactive and/or immunoreactive IL-6 concentration determination. In neutralizing studies, $C M$ was pre-incubated with goat anti-human $I L 1 \beta$ neutralizing antibody or antiTNF $\alpha$ antibody $(1 \mu \mathrm{g} / \mathrm{ml})$ or both.

Comparison of IL-6 secretion by rat ATII cells and rat alveolar macrophages. We compared the secretion of bioactive IL- 6 by rat ATII cells and rat alveolar macrophages cultured in similar conditions. $10^{6}$ alveolar macrophages were cultured for $24 \mathrm{~h}$ in $500 \mu \mathrm{l}$ RPMI with $5 \%$ heat-inactivated fetal bovine serum, antibiotics and glutamine with or without $2 \mathrm{ng} / \mathrm{ml}$ recombinant murine IL-1 $\beta$. The supernatants were recovered and stored at $-20^{\circ} \mathrm{C}$ until IL-6 assay. Similarly, $10^{6}$ rat ATII cells were allowed to adhere on 24-well cell culture plates for $24 \mathrm{~h}$ in complete DME with $10 \%$ fetal bovine serum. Then the non adherent cells were removed by washing and adherent ATII cells were cultured for $24 \mathrm{~h}$ in $500 \mu \mathrm{l}$ complete DME with 5\% heat-inactivated fetal bovine serum with or without $2 \mathrm{ng} / \mathrm{ml}$ recombinant murine IL- $1 \beta$. Supernatants were collected for bioactive IL-6 concentration determination. Then the alveolar macrophages and rat ATII cells were removed with trypsinEDTA and the cells were counted. The IL- 6 concentration in alveolar macrophages and ATII cell culture supernatants was expressed as pg/ $\mathrm{ml} / 10^{6}$ adherent cells.

Immunohistochemistry for detection of IL-6. To determine whether ATII cells synthesized IL-6 in vivo, a combined IL-6 immunodetection and alkaline phosphatase activity revelation procedure was applied to the cryostat sections from normal lung biopsies (obtained from four patients undergoing surgical lung resection for a localized lung tumor) and from the lung biopsies from three patients who underwent unilateral lung transplantation for advanced idiopathic interstitial pulmonary fibrosis. All lung biopsies were immediately frozen in nitrogen liquid after resection and stored at $-80^{\circ} \mathrm{C}$ until use. The IL- 6 detection procedure, then the alkaline phosphatase procedure, were applied sequentially. 


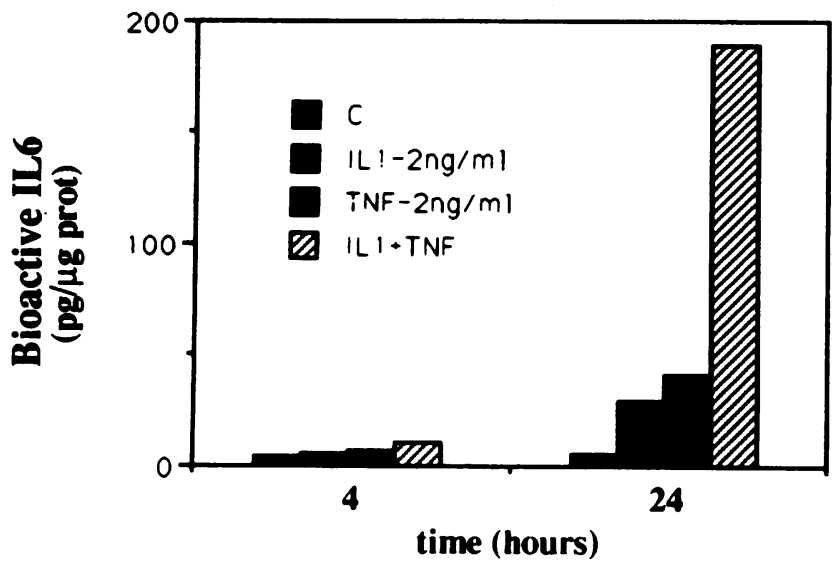

Figure 1. Bioactive IL-6 in rat alveolar type II cells supernatants. Rat ATII cells monolayers were stimulated with recombinant murine TNF $\alpha$ or IL- $1 \beta$ for 4 and $24 \mathrm{~h}$. Bioactive IL-6 concentration was determined using the B9 cell proliferation assay. Data are from a typical experiment representative of three different experiments.

This allowed us to detect on the same section the cells that were antiIL-6 positive and those that were alkaline phosphatase positive.

Cryostat sections $(8 \mu \mathrm{m})$ were fixed in acetone for $10 \mathrm{~min}$ at room temperature, air dried, rehydrated in PBS, then incubated with a normal goat serum for $5 \mathrm{~min}$ to avoid nonspecific binding. Excess serum was tipped off, and lung sections were overlaid for $20 \mathrm{~min}$ with a polyclonal rabbit anti-human IL-6 antiserum (1:100 vol/vol in PBS containing $0.1 \%$ BSA). After several washes in PBS, lung sections were incubated for $20 \mathrm{~min}$ with a biotinylated goat anti-rabbit antibody, then incubated with streptavidin-peroxidase (ICN Biomedicals, Costa Mesa, CA) for $20 \mathrm{~min}$ and washed in distilled water. Peroxidase reaction was then revealed by diaminobenzidine (Vector Labs, Burlingame, CA) and $\mathrm{H}_{2} \mathrm{O}_{2}$. Anti-IL-6 positive cells appeared brown. Sections were counterstained with Harris hematoxylin (Ortho Diagnostic Systems, Bucks, England). Sections where the first antibody was omitted or where preimmune rabbit serum was used instead of the anti-IL- 6 antibody were used as controls in order to assess the specificity of the immunolabeling.

Type II pneumocytes were characterized according to their alkaline phosphatase activity as previously described by Edelson et al. (28). A stock solution of enzyme substrate was prepared by dissolving $30 \mathrm{mg}$ of naphtol-AS-phosphate in $0.5 \mathrm{ml}$ of $\mathrm{N}, N$-dimethylformamide (Sigma Chemical Co.) and diluting to $100 \mathrm{ml}$ of $0.2 \mathrm{M}$ Tris buffer previously adjusted to $\mathrm{pH}$ 9.1. Immediately before staining, the Fast Blue BB salt (Sigma Chemical Co.) was added to the stock substrate solution (1 mg/ $\mathrm{ml}$ ) and filtered. After the peroxidase was revealed, the sections were incubated with the staining solution for $45 \mathrm{~min}$ at $37^{\circ} \mathrm{C}$ and washed in distilled water. Alkaline phosphatase positive cells appeared blue.

In some experiments, rat ATII cells were grown on coverslips, stimulated with $\mathrm{rmL}-1 \beta(2 \mathrm{ng} / \mathrm{ml})$ for $24 \mathrm{~h}$ then immunostained with the anti-IL-6 antiserum. In preliminary experiments, we observed that the anti-human IL-6 antiserum cross-reacted with rat IL-6 since it neutralized the IL- 6 bioactivity contained in rat alveolar macrophage supernatants.

Statistical analysis. Data are expressed as means \pm SEM. Groups of data were evaluated by analysis of variance (ANOVA). Data that appeared significantly different were compared by Student's $t$ test for comparing the means of multiple groups, and considered significant if $P$ values were $<0.05$.

\section{Results}

IL-6 secretion by rat ATII cells. Rat ATII cells in primary culture spontaneously secreted IL-6 bioactivity in cell culture supernatants (Fig. 1). IL-6 secretion was increased 2-3-fold

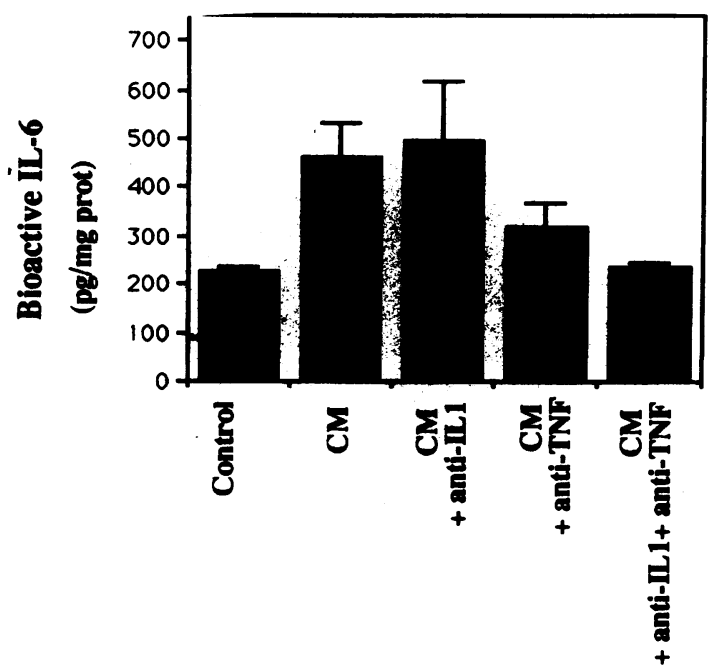

Figure 2. LPS-stimulated rat alveolar macrophages conditioned media (CM) increased IL-6 secretion by rat alveolar type II cells. Preincubation of the CM with the combination of anti-murine IL-1 and antimurine TNF $\alpha$ antibodies inhibited the increase in IL-6 secretion ( $P$ $<0.05$ when compared with CM alone). Bioactive IL- 6 concentration was determined using the B9 cell proliferation assay. Data are mean \pm SEM from three different experiments performed in triplicates.

when ATII cells were incubated for $4 \mathrm{~h}$ with $\mathrm{rmIL}-1 \beta$ or $\mathrm{rmTNF} \alpha(2 \mathrm{ng} / \mathrm{ml})$. The effect of these cytokines on rat ATII cell $\mathrm{IL}-6$ secretion was time dependent. Moreover, the combination of IL- $1 \beta$ and TNF $\alpha$ ( $2 \mathrm{ng} / \mathrm{ml}$ each) increased IL- 6 secretion by rat ATII cells in a supra-additive way when studied after a 24-h stimulation period. We looked for the stimulatory effect of rat AM secretory products. Rat AM-CM increased IL-6 secretion by ATII cells. The stimulation was essentially due to the combination of IL- 1 and TNF $\alpha$ contained in AM-CM since the preincubation of the AM-CM with the combination of anti-IL$1 \alpha$ and anti-TNF $\alpha$ antibodies abolished the stimulatory effect of AM-CM (Fig. 2). Anti-TNF $\alpha$ alone tended to reduce IL-6 secretion without reaching statistical significance $(P=0.08$ when compared with $\mathrm{CM}$ alone). In order to confirm that rat ATII cells were the source of IL-6 in vitro, we performed IL6 immunostaining on ATII cells. Unstimulated rat ATII cells were weakly labeled whereas IL- $1 \beta$ stimulated ATII cells exhibited a strong cytoplasmic immunostaining (Fig. 3).

Comparison of IL-6 secretion by rat ATII cells and rat alveolar macrophages. To assess the quantitative importance of IL- 6 secretion by ATII cells, we compared IL- 6 secretion by rat ATII cells with that of rat alveolar macrophages (Fig. 4). Spontaneous IL-6 secretion by rat ATII cells amounted to $5690 \pm 770 \mathrm{pg} / \mathrm{ml} / 10^{6}$ cells $(n=12)$ and was fivefold higher than spontaneous rat alveolar macrophages IL-6 secretion $\left(1052 \pm 286 \mathrm{pg} / \mathrm{ml} / 10^{6}\right.$ cells, $\left.n=8, P=0.001\right)$. IL-6 secretion by ATII cells was increased by $48 \%$ with IL- $1 \beta$ stimulation ( $8486 \pm 632 \mathrm{pg} / \mathrm{ml} / 10^{6}$ cells, $n=12, P=0.01$ when compared with spontaneous secretion) and was two-fold higher than IL$1 \beta$ stimulated rat alveolar macrophages IL-6 secretion (3844 $\pm 566 \mathrm{pg} / \mathrm{ml} / 10^{6}$ cells, $n=8, P=0.001$ ).

IL-6 secretion by human pulmonary epithelial-derived cells (A549 cell line). We studied IL-6 secretion by the A549 human 

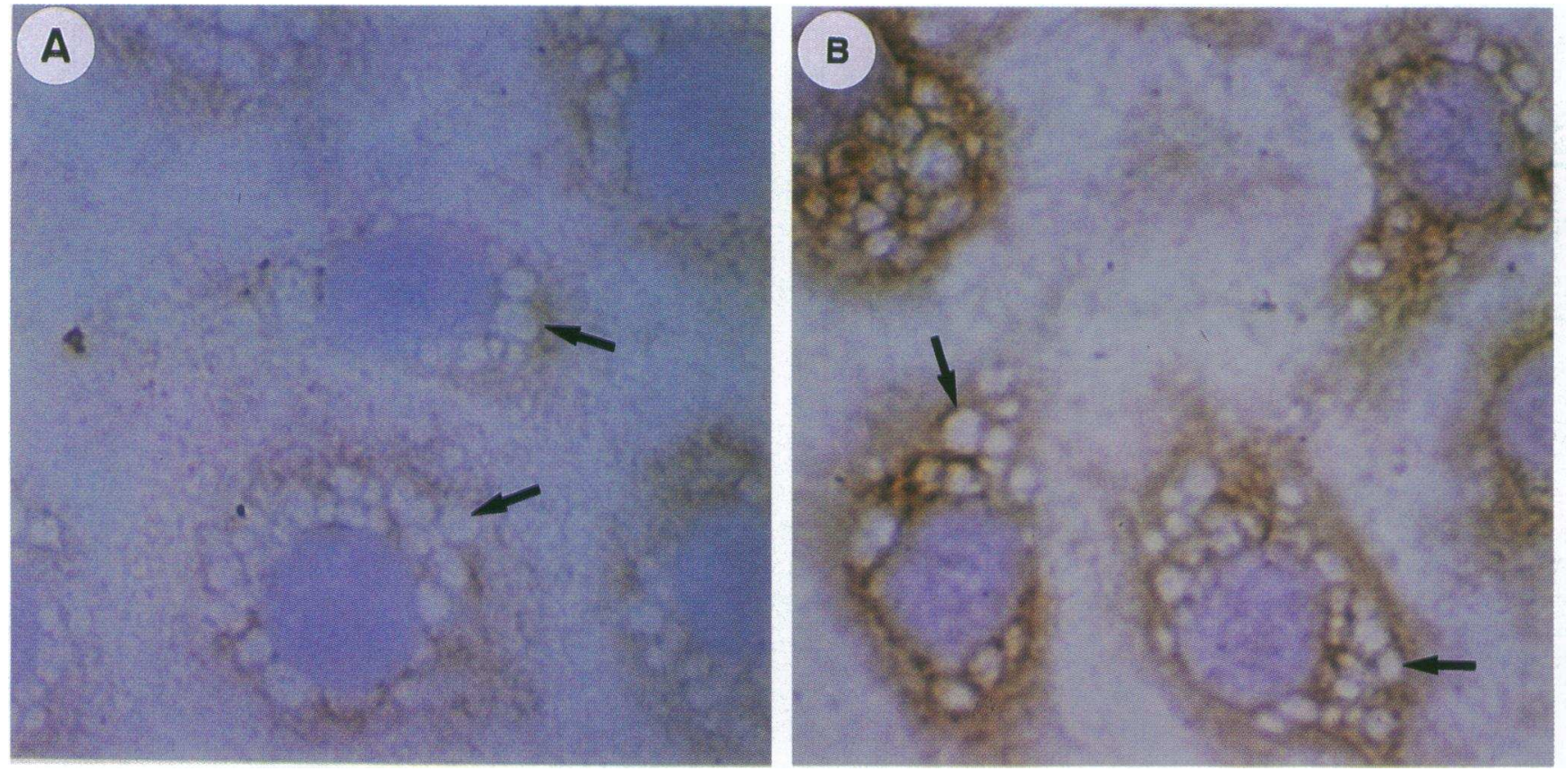

Figure 3. IL-6 immunostaining on rat alveolar type II cells in primary culture. Unstimulated rat alveolar type II cells were weakly labeled ( $A$ ) whereas IL-1 $\beta$-stimulated cells exhibited a strong cytoplasmic immunostaining $(B)$. Alveolar type II cells were easily identified with their characteristic intra-cellular lipidic inclusions $($ arrows). (original magnification $\times 500$ )

cell line as a model of human ATII cells. Confluent A549 cell monolayers were stimulated at time 0 with either $20 \mathrm{ng} / \mathrm{ml}$ rhTNF $\alpha$ or $20 \mathrm{ng} / \mathrm{ml}$ rhIL- $1 \beta$ and assessed for the time-dependent generation of bioactive IL-6. As shown in Fig. 5, treatment of A549 cell with TNF $\alpha$ or IL- $1 \beta$ resulted in the production of substantial bioactive IL- 6 that was seen as early as $1 \mathrm{~h}$, reached its maximum at $12 \mathrm{~h}$ and then plateaued. Bioactive IL- 6 concentration was $20-30$-fold higher in IL- $1 \beta$ treated than in TNF $\alpha$ treated A549 cell. Untreated cell supernatants contained IL-6 bioactivity that was at the lower limit of the assay sensitivity and did not increase after $24 \mathrm{~h}$ of culture.

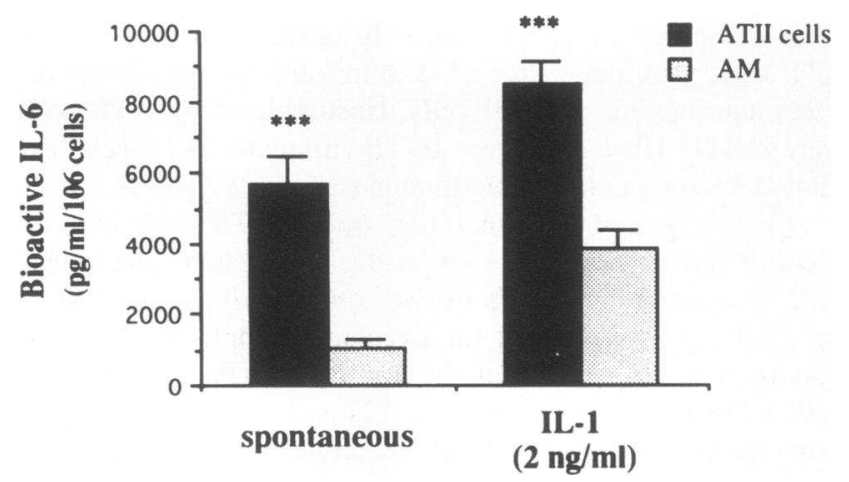

Figure 4. Comparison of IL-6 secretion by rat alveolar type II cells (ATII cells) and rat alveolar macrophages (AM). Spontaneous IL-6 secretion by rat ATII cells was fivefold higher than spontaneous rat alveolar macrophages IL-6 secretion $(P=0.001)$. IL-1 $\beta$ stimulated IL6 secretion by ATII cells was twofold higher than IL- $1 \beta$ stimulated rat alveolar macrophages IL-6 secretion $(P=0.001)$. Values are mean \pm SEM from four different experiments performed in duplicate (AM) or triplicate (ATII cells). $* * * P=0.001$.
The stimulating effect of TNF $\alpha$ and IL- $1 \beta$ was dose-dependent as shown in Fig. 5. Confluent monolayers of A549 cell were stimulated for $24 \mathrm{~h}$ with either $0.02-20 \mathrm{ng} / \mathrm{ml}$ rhIL- $1 \beta$ or $\operatorname{rhTNF} \alpha$. For IL- $1 \beta$, concentrations as low as $0.02 \mathrm{ng} / \mathrm{ml}$ induced the secretion of bioactive IL- 6 in the A549 cell supernatant that was maximal at $0.2 \mathrm{ng} / \mathrm{ml}$ and did not further increase. For $\mathrm{TNF} \alpha$, higher concentrations were needed to observe a detectable concentration of bioactive IL-6 in A549 cell supernatants. Indeed, bioactive IL- 6 was consistently detected with 0.2 $\mathrm{ng} / \mathrm{ml} \mathrm{TNF} \alpha$ and was maximal with $20 \mathrm{ng} / \mathrm{ml} \mathrm{TNF} \alpha$.

To determine whether IL-6 activity was due to antigenic IL-6, supernatants of TNF $\alpha$ and IL- $1 \beta$ stimulated A549 monolayers were assayed for antigenic IL- 6 by ELISA. Fig. 6 demonstrates the time- and dose-dependent generation of immunoreactive IL- 6 by A549 cells under stimulation. For both cytokines immunoreactive IL-6 concentrations were significantly increased $2 \mathrm{~h}$ after stimulation, were maximal $4 \mathrm{~h}$ after stimulation and then plateaued. The maximal stimulation was obtained with $2 \mathrm{ng} / \mathrm{ml}$ concentrations of stimulants in the medium. Higher concentrations did not further increase the IL-6 secretion in the A549 cell supernatant. Time- and dose-response curves were similar to that obtained for bioactive IL-6. Immunoreactive IL6 was not detected in the supernatant of unstimulated A549 cells. Costimulation of A549 cells with $\mathrm{IL}-1 \beta(2 \mathrm{ng} / \mathrm{ml})$ and $\mathrm{TNF} \alpha(2 \mathrm{ng} / \mathrm{ml})$ resulted in an additive response (Fig. 7).

Time- and dose-dependent expression of steady state IL-6 mRNA by A549 cells. To determine whether A549 epithelial cells expressed mRNA for IL-6, A549 cell monolayers were stimulated at time 0 with $0.2,2$, or $20 \mathrm{ng} / \mathrm{ml} \mathrm{rhIL-} \beta$ and rhTNF $\alpha$, and at specific time intervals total RNA was extracted. As shown in Figs. 8 and 9, we could not detect IL-6 mRNA in unstimulated A549 cells. By contrast IL- $1 \beta$ and TNF $\alpha$ induced the expression of IL- 6 mRNA in A549 cells. Maximal IL-6 mRNA expression was seen $4 \mathrm{~h}$ after stimulation with IL- $1 \beta$ and 


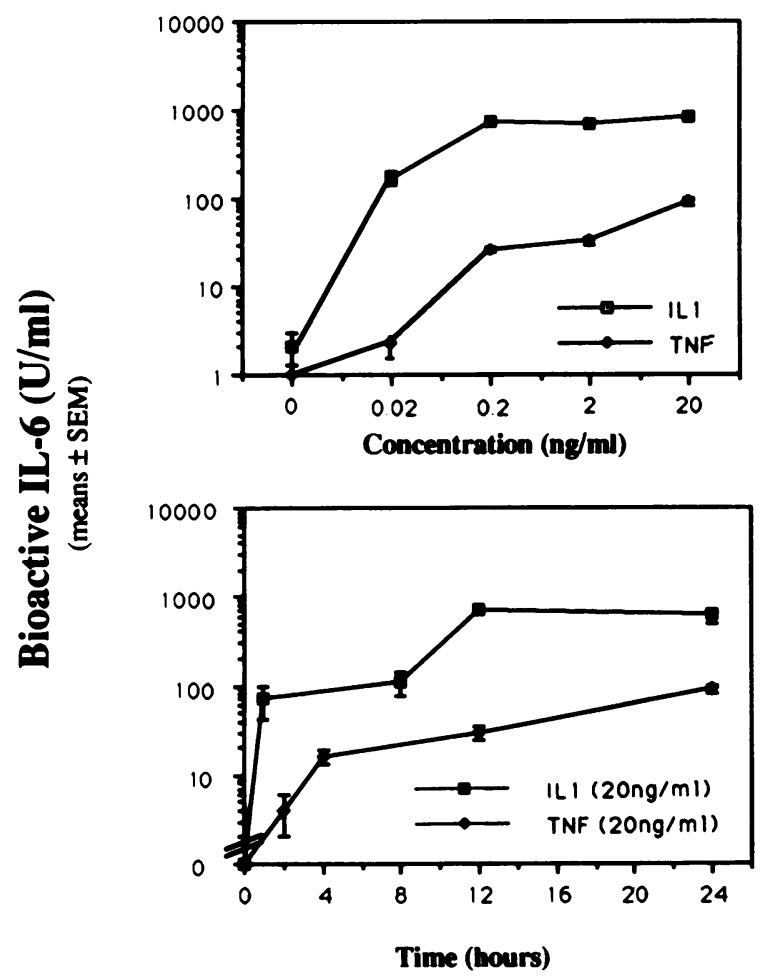

Figure 5. Bioactive IL-6 in A549 pulmonary epithelial cells supernatants. TNF $\alpha$ and IL- $1 \beta$-stimulated A549 cells secreted bioactive IL-6 in a time- and dose-dependent fashion, whereas unstimulated cells did not. Bioactive IL-6 was determined using the B9-cell line proliferation assay. Values are means \pm SEM of two different experiments performed in triplicates. Note the logarithmic scale.

$2 \mathrm{~h}$ after stimulation with TNF $\alpha$. Minimal residual expression of IL-6 mRNA was detected $24 \mathrm{~h}$ after IL- $1 \beta$ or TNF $\alpha$ stimulation.

IL- $1 \beta$ concentrations as low as $0.2 \mathrm{ng} / \mathrm{ml}$ induced a maximal expression of IL- 6 mRNA as detected by the Northern blot analysis (Fig. 8). TNF $\alpha$ stimulated the expression of IL-6 mRNA by A549 cells in a dose-dependent fashion, the threshold concentration causing the expression of $\mathrm{IL}-6$ mRNA was 0.2 ng/ml (Fig. 9).

Induction of A549 cell immunoreactive IL-6 secretion and IL-6 mRNA expression by LPS-stimulated human AM and THPI cell conditioned media. To investigate whether AM or THP1 cell could induce the secretion of IL- 6 by A549 cells through the secretion of soluble factors, A549 cells were cultured for 24 h with complete Ham's F12 medium containing 10\% LPS stimulated human AM- or THP1-CM. As shown in Fig. 10, AM$\mathrm{CM}$ strongly increased the concentration of immunoreactive IL6 in A549 cell supernatants. The stimulation was higher than that observed with maximal stimulating concentrations of IL$1 \beta$ and TNF $\alpha(20 \mathrm{ng} / \mathrm{ml})$. This was not due to a direct effect of LPS contained in AM-CM since LPS alone (0.1-100 $\mu \mathrm{g} /$ $\mathrm{ml}$ ) had no effect. Preincubation of AM-CM with a goat antihuman IL- $1 \beta$ neutralizing antibody resulted in a $53 \pm 2 \%$ reduction in immunoreactive IL-6 in A549 cell supernatants.

We obtained quite similar results when A549 cell were incubated with THP1-conditioned media (Fig. $11 A$ ). Indeed, the anti-human IL- $1 \beta$ antibody decreased the IL- 6 concentration by $47 \pm 6 \%$. The anti-human TNF $\alpha$ antibody decreased the IL-6 concentration by $17 \pm 3 \%$. The IL- 6 concentration in A549 cell

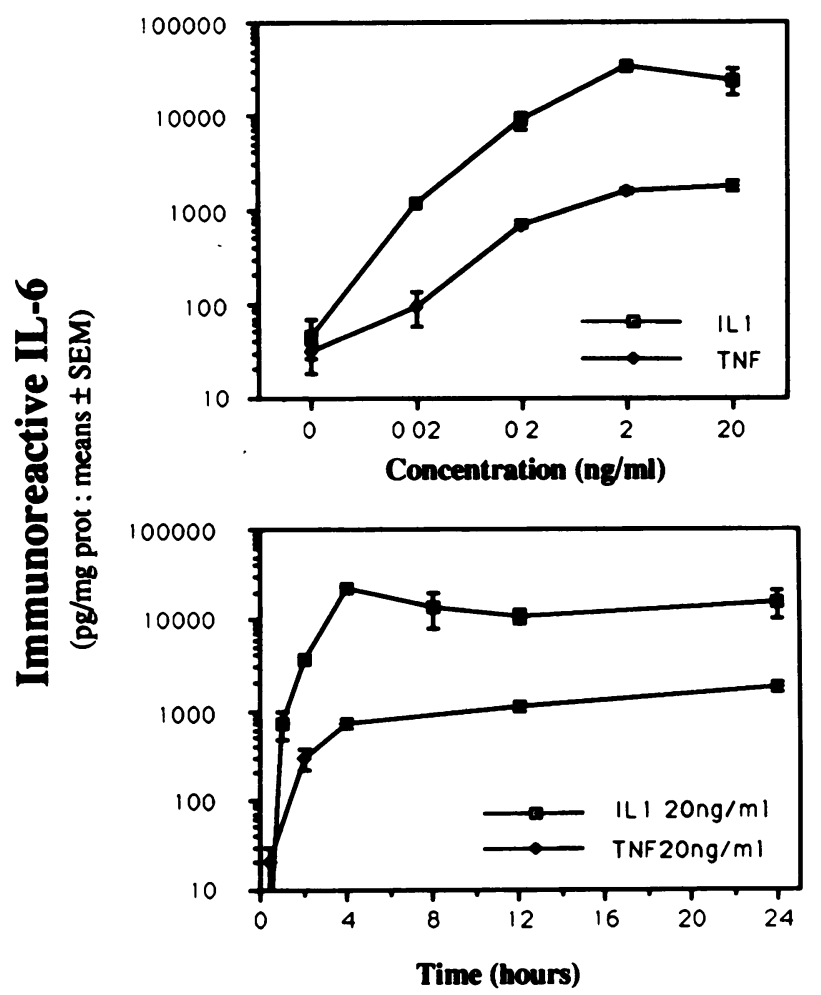

Figure 6. Expression of immunoreactive IL-6 in A549 pulmonary epithelial cell supernatants. TNF $\alpha$ and IL-1 $\beta$-stimulated A549 cells secreted immunoreactive IL- 6 in a time- and dose-dependent fashion, whereas unstimulated cells did not. Immunoreactive IL-6 was determined using an ELISA kit. Values are means \pm SEM of two different experiments performed in triplicates. Note the logarithmic scale.

supernatants was further decreased by adding both antibodies. Persistent immunoreactive IL-6 that was detected corresponded to the IL-6 present in THP1-CM added to the A549 cell for stimulation ( shaded area in Fig. $11 A$ ). Inhibition of IL-6 secretion was due to a reduction in the expression of steady-state

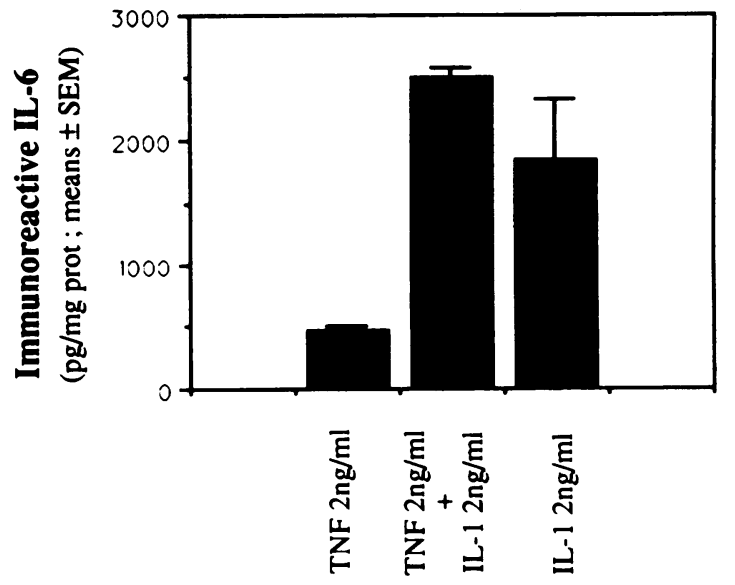

Figure 7. The costimulation of A549 cells with IL-1 $\beta$ and TNF $\alpha$ resulted in an additive response. Cells were cultured for $4 \mathrm{~h}$ with IL- $1 \beta$ $(2 \mathrm{ng} / \mathrm{ml}), \mathrm{TNF} \alpha(2 \mathrm{ng} / \mathrm{ml})$ or both. Immunoreactive IL-6 was measured using an ELISA kit. Values are from three different experiments performed in triplicates. 


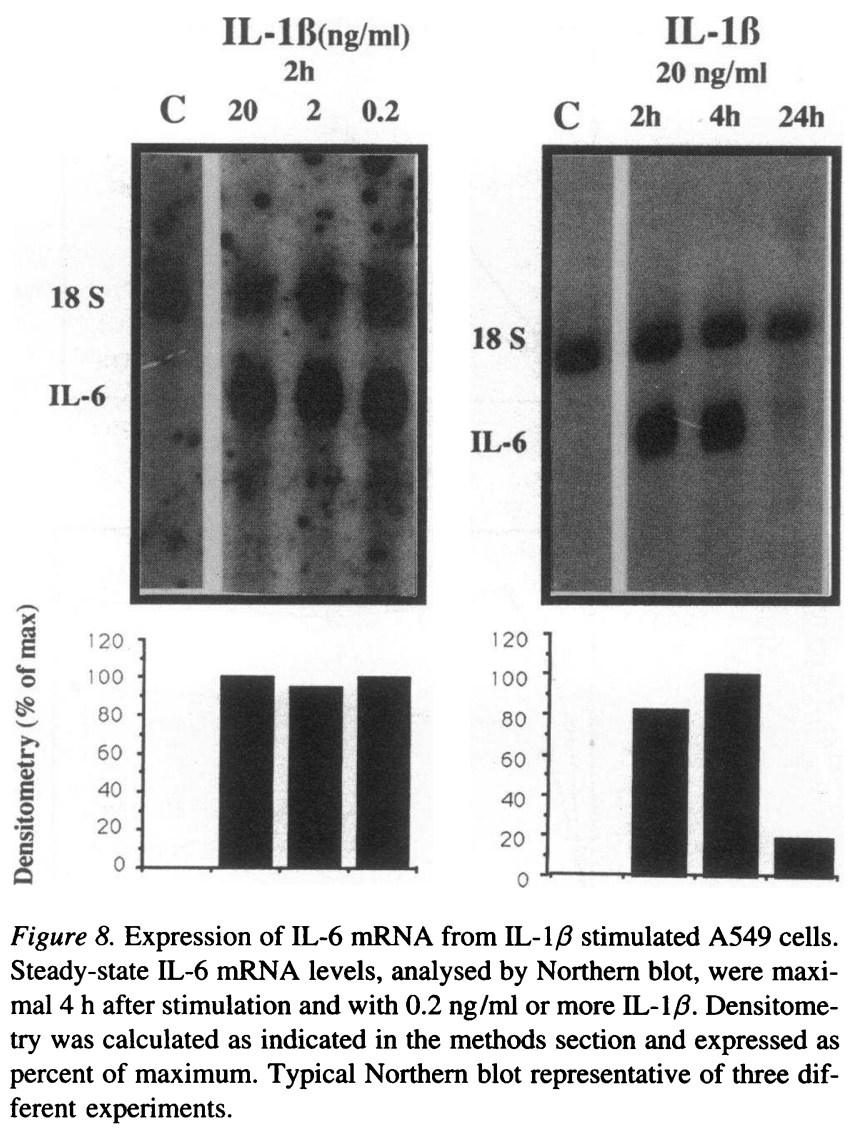

IL-6 mRNA induced by THP1 conditioned-media. As shown in Fig. $11 B$, pre-incubation of THP1-CM with both anti-IL$1 \beta$ and anti-TNF $\alpha$ completely inhibited the expression of steady-state IL- 6 mRNA induced by THP1 conditioned-media, whereas each antibody by itself only reduced the steady-state IL-6 mRNA.

Synergic effect of LPS and IFN $\gamma$ on the immunoreactive IL-6 secretion and the expression of steady-state IL-6 mRNA by $A 549$ cells. IFN $\gamma$ is one of the major T cell-derived cytokine involved in the activation of monocytes/macrophages during the initiation of the immune response. We asked whether IFN $\gamma$ could induce the expression of IL- 6 by A549 cell and whether it could cooperate with LPS for this purpose. A549 monolayers were stimulated for 24 hours with LPS $(0.1-100 \mu \mathrm{g} / \mathrm{ml})$ or IFN $\gamma(20 \mathrm{ng} / \mathrm{ml})$ or both. As shown in Fig. $12 A$, immunoreactive IL-6 concentration in supernatants of A549 cells incubated for $24 \mathrm{~h}$ with LPS alone was not different of IL-6 concentration measured in unstimulated cell supernatants. In contrast, IFN $\gamma$ stimulated A549 cells generated IL-6 and the combination of IFN $\gamma$ and LPS induced a dose-dependent increase of immunoreactive IL-6 in A549 cell supernatants. Similarly, IFN $\gamma$ induced a small expression of IL-6 mRNA, whereas LPS alone did not. However, the combination of IFN $\gamma$ and LPS induced a dose-dependent expression of IL-6 mRNA by A549 cells (Fig. $12 \mathrm{~B}$ ).

Clearly, although LPS did not directly stimulate the IL-6 mRNA expression and IL-6 secretion in A549 cell, LPS could influence the magnitude of the stimulation effect of IFN $\gamma$.

Immunohistochemical staining. To determine whether these in vitro observations could have an in vivo significance, we

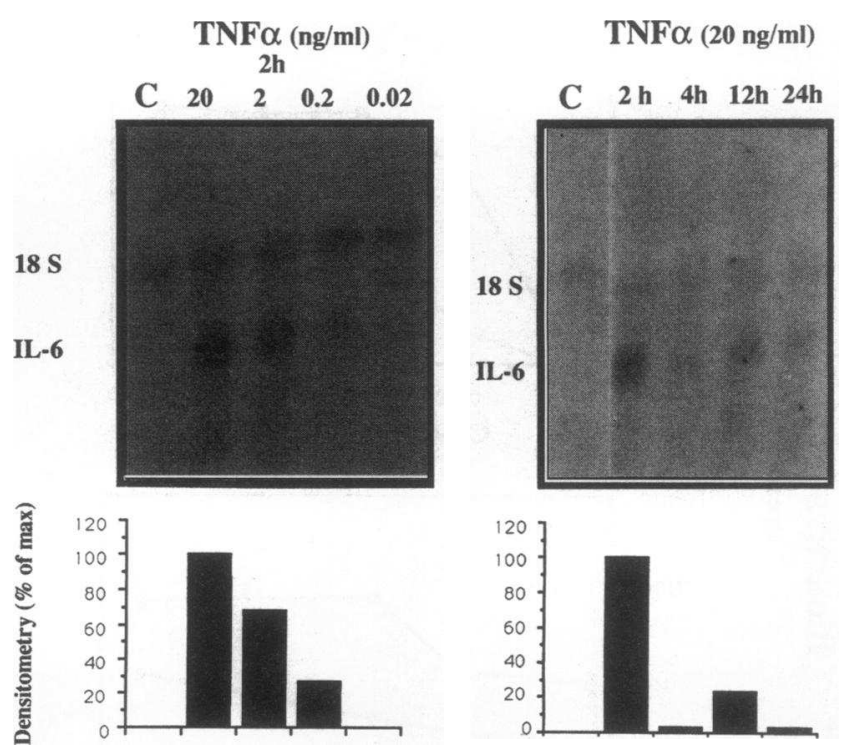

Figure 9. Expression of IL-6 mRNA from TNF $\alpha$-stimulated A549 cells. Steady-state IL-6 mRNA was maximal $2 \mathrm{~h}$ after stimulation, as assessed by Northern blot analysis. The threshold concentration of TNF $\alpha$ causing IL-6 mRNA expression was $0.2 \mathrm{ng} / \mathrm{ml}$. Densitometry was expressed as percent of maximum. Typical Northern blot representative of three different experiments.

looked for the expression of immunoreactive IL- 6 protein in the alveolar epithelium in the normal human lung and in idiopathic interstitial pulmonary fibrosis, a situation where alveolar macrophages have been shown to be chronically activated.

In normal lung, ATII cells were identified by their accumulation of blue reaction product according to alkaline phosphatase staining. The cells were largely cuboidal in shape and located in alveolar "corners". These cells did not stain with the antiIL-6 serum in all the sections examined (Fig. 13, $A$ and $B$ ).

By contrast, immunohistochemistry demonstrated the expression of immunoreactive IL- 6 by hyperplastic ATII cells in

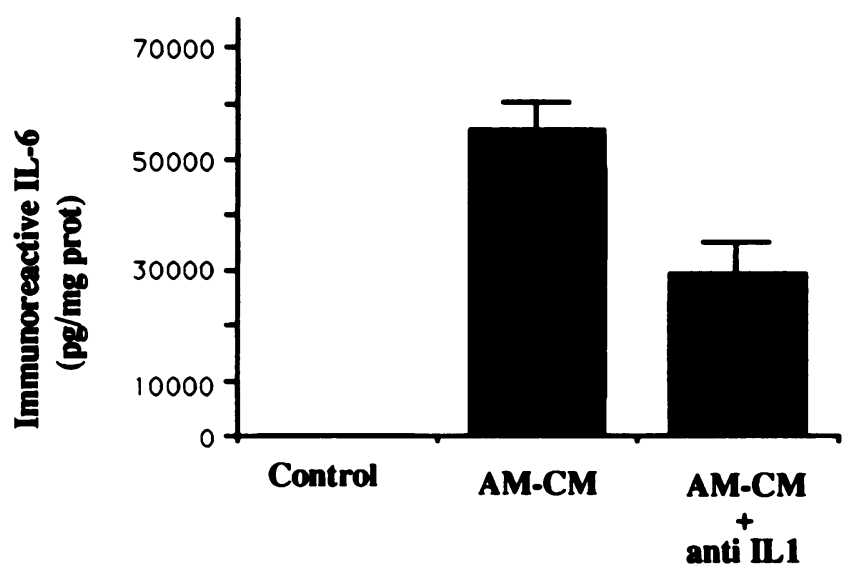

Figure 10. Expression of immunoreactive IL-6 in supernatants of A549 cells cultured with LPS-stimulated AM-conditioned media (AM-CM). AM-CM greatly increased the IL- 6 concentrations in A549 cells supernatants. Preincubation of AM-CM with anti-IL- $1 \beta$ antibody reduced by $53 \% \mathrm{IL}-6$ concentrations whereas control goat IgG did not (data not shown). 

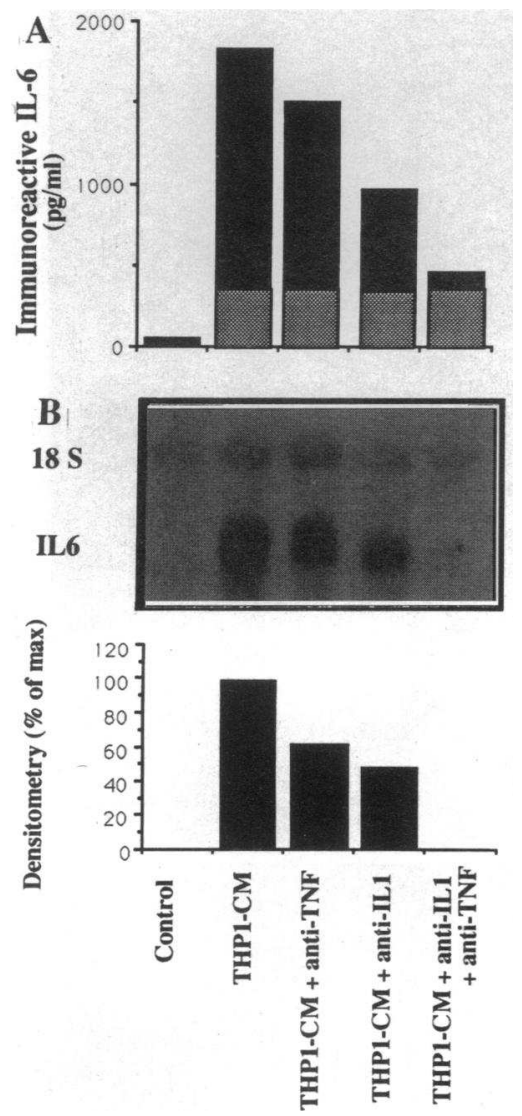

Figure 11. Expression of immunoreactive IL-6 (A) and steady-state IL6 mRNA (B) by A549 pulmonary epithelial cells cultured with LPSstimulated THP1-conditioned media (THP1CM). Preincubation of THP1-CM with antiTNF $\alpha$, anti-IL- $1 \beta$ or both resulted in a decreased expression of immunoreactive IL-6 and steady-state IL-6 mRNA, whereas control rabbit antiserum or control goat IgG did not (data not shown). The dashed area represents the IL-6 concentration contained in THP1-CM. Densitometry was expressed as percent of maximum. Values and Northern blot are from one experiment representative of three different experiments.

interstitial pulmonary fibrosis (Fig. 13, C and D). Anti-IL-6 immunostaining colocalized with alkaline phosphatase activity. The specificity of this immunostaining reaction was tested by incubating lung sections with pre-immune rabbit serum instead of rabbit anti-IL-6 antiserum. In these conditions, labeling was abolished. These results were uniform and reproducible in all sections studied from the lung biopsies of the three patients studied.

\section{Discussion}

Our study strongly suggests that alveolar epithelial cells may be one potential source of intra-alveolar IL-6. Indeed, we show that in vitro $(a)$ rat ATII cells supernatants contain biologically active IL-6 that is highly increased with IL- $1 \beta$, TNF $\alpha$, and AMCM stimulation, $(b)$ cytokine-stimulated human pulmonary epithelial-derived A549 cells express the IL-6 gene and generate immunoreactive and bioactive IL-6 whereas unstimulated A549 cells do not, and (c) in vivo, normal ATII cells do not express immunoreactive IL-6 whereas hyperplastic alveolar epithelial cells in interstitial pulmonary fibrosis do. This IL-6 secretion by ATII cells is potentially important since it is 2-5-fold higher than alveolar macrophage in vitro IL-6 secretion on a cell per cell basis.

$\mathrm{IL}-6$ is one of the principal mediators of the acute inflammatory response (29). IL-6 is secreted at the site of inflammation but may be detected in the serum of patients at levels higher than those at which this cytokine elicits effects on cells in culture (9). Measurable levels of IL-6 have been detected in the epithelial lining fluid of normal subjects, as retrieved by
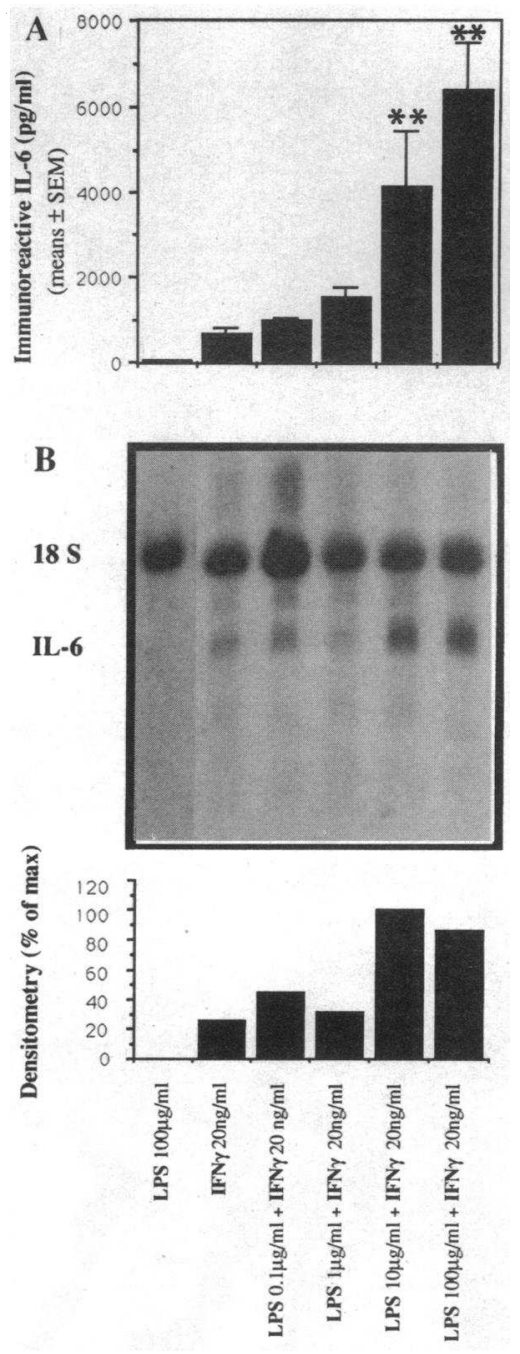

Figure 12. Effect of IFN $\gamma$ and LPS on the expression of immunoreactive IL-6 $(A)$ and steadystate IL-6 mRNA $(B)$ by A549 pulmonary epithelial cells. IFN $\gamma(20 \mathrm{ng} /$ $\mathrm{ml}$ ) induced the expression of immunoreactive IL-6 and IL-6 mRNA whereas LPS alone (up to $100 \mu \mathrm{g} / \mathrm{ml}$ ) did not. By contrast, LPS increased the expression of immunoreactive IL-6 in a dose-dependent manner in the presence of IFN $\gamma$, and also increased the expression of steadystate IL-6 mRNA. Densitometry was expressed as percent of maximum. Immunoreactive IL-6 levels are mean \pm SEM from three different experiments performed in triplicates $(* * P<0.01$ when compared with IFN $\gamma$ stimulated cells ). Northern blot is from one experiment representative of three different experiments.

BAL. BAL IL-6 levels are greatly increased in various lung diseases $(15,16,30)$. This increased IL-6 level in BAL recovered from patients may be derived from several sources. The first one may be a passive diffusion of IL-6 from plasma into the epithelial lining fluid since detectable concentrations of IL6 are present in the serum of patients with infectious and inflammatory diseases (31). A second source of IL-6 could be a local production by inflammatory and non-inflammatory lung cells. Indeed, alveolar macrophages $(22,32)$, lung fibroblasts (32), endothelial cells (12), and bronchial epithelial cells (33) have been shown to generate IL-6 in vitro when appropriately stimulated. Alveolar macrophages recovered by BAL have been shown to express the IL-6 mRNA by in-situ hybridization in certain pathological conditions (34).

We observed that rat ATII cell supernatant contained bioactive IL-6 as detected by the B9 hybridoma cell line proliferation assay. These results suggested that rat ATII cells in primary culture secreted IL-6 in vitro. When using ATII cells in primary culture, all the results must be viewed in the light of the possible role of contaminating non epithelial cells such as alveolar macrophages. However, quantitative comparison of IL-6 secretion by alveolar macrophages and ATII cells clearly shows that in vitro unstimulated rat ATII cells secrete fivefold more IL-6 than alveolar macrophages on a cell per cell basis. Therefore, the 

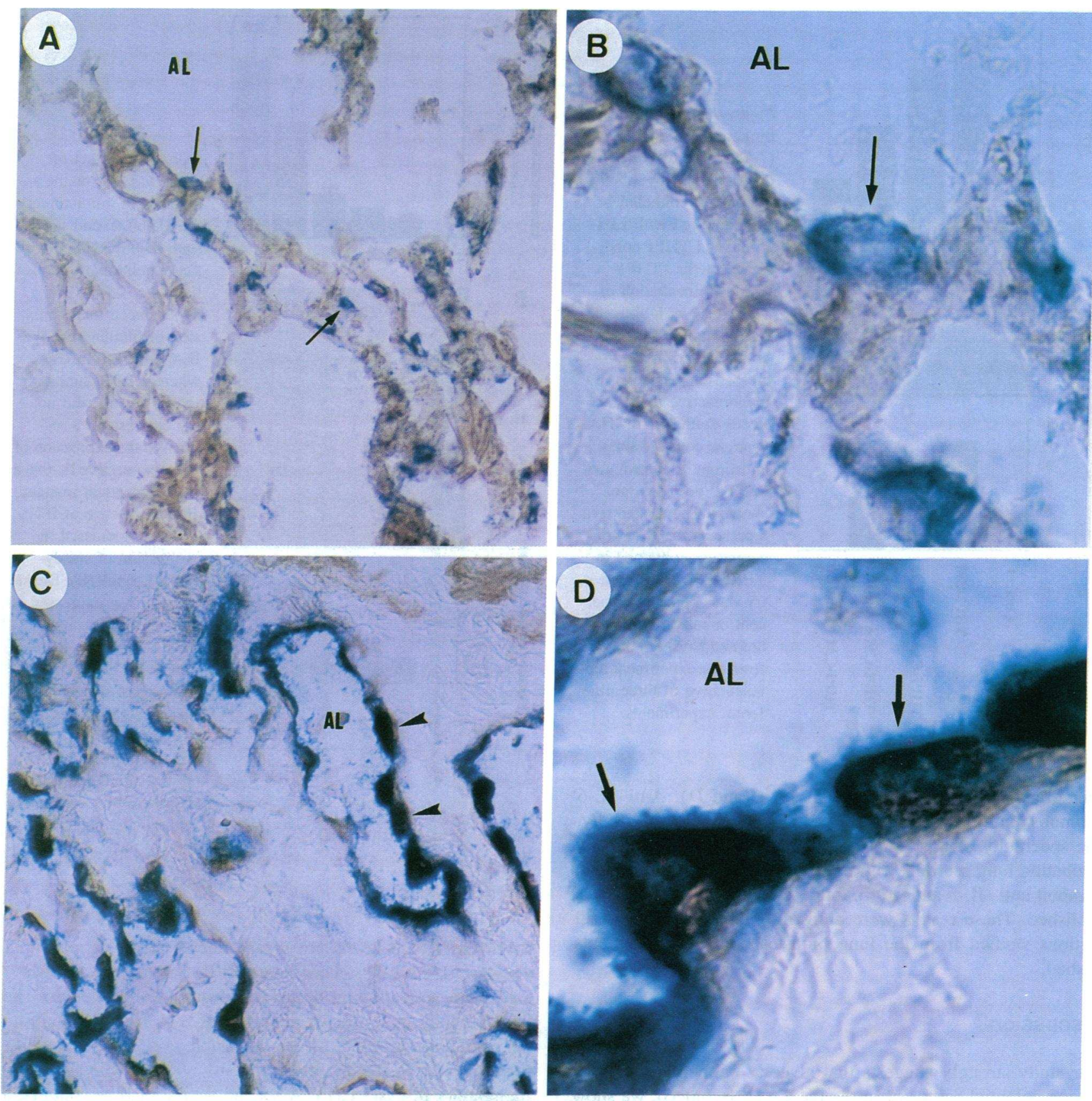

Figure 13. Immunohistochemical detection of IL-6 in normal lung tissue and in fibrotic lung. $(A)$ In a normal lung biopsy, the type II alveolar cells (arrows) identified from their alkaline phosphatase activity (blue label) are not immunostained with the anti-IL-6 antiserum (original magnification $\times 100)$. (B) Higher magnification view of a type II alveolar epithelial cell $($ arrow $)(\times 500)$. ( $C$ ) In lung fibrosis, hyperplastic alveolar epithelial cells (arrowheads) are strongly immunostained with the anti-IL-6 antiserum (brown label) and also express an endogenous alkaline phosphatase activity (original magnification $\times 200$ ). (D) Higher magnification view of some double-labeled alveolar epithelial cells $($ arrows) (original magnification $\times 1,000$ ). $A L$, alveolar lumen.

role of contaminating alveolar macrophages in the in vitro ATII cells global IL-6 secretion is probably very low if not absolutely negligible. Moreover, we detected immunoreactive IL-6 in the cytoplasm of ATII cells cultured in vitro, using immunostaining (Fig. 3) and we have shown that IL-6 is readily detectable in hyperplastic alveolar epithelial cells in the human fibrotic lung (Fig. 13, $C$ and $D$ ). Taken together, our in vitro and in vivo results show that ATII cells are a source of IL-6 in the alveolar space. However, although rat ATII cells in primary culture spontaneously secreted bioactive IL-6, ATII cells in normal human lung did not express any detectable immunoreactive IL6. These results suggest that the processes of primary culture activate ATII cells to produce IL-6.

To extend to human alveolar epithelial cells our results obtained on rat ATII cells, we looked for and characterized the in vitro secretion of IL- 6 by a pulmonary human epithelial-derived cell-line (A549). This cell line has been previously used as a model of alveolar epithelial cell $(2,4,20,21)$. However, IL- 
$1 \beta$, TNF $\alpha$, and IFN $\gamma$ induced A549 cells to express IL-6 mRNA and secrete immunoreactive and bioactive IL-6, whereas LPS alone had no effect. Among the cytokines that we tested, IL$1 \beta$ was the most potent inducer of IL-6 expression in A549 cell, much more potent than TNF $\alpha$. IL- $1 \beta$ and TNF $\alpha$ were certainly involved in the stimulatory effect of AM- and THP1$\mathrm{CM}$ as assessed by the striking inhibition of IL-6 mRNA expression by anti-IL- $1 \beta$ and anti-TNF $\alpha$ antibodies. IL- $1 \beta$ and TNF $\alpha$ had almost an additive effect on IL-6 production by A549 cell, and their effect was supra-additive on rat ATII cells. Elias and Lentz (11) reported that IL-1 and TNF synergistically stimulate fibroblast IL-6 production.

LPS alone did not stimulate the expression of IL- 6 by A549 cell. By contrast, LPS has been shown to increase the secretion of the C3 complement component by A549 cell, whereas it had no effect on the C5 component production or total protein synthesis (20). In the present study, we showed that LPS and IFN $\gamma$ acted synergistically to increase the steady-state level of IL-6 mRNA and the secretion of immunoreactive IL-6 by A549 cell. IFN $\gamma$ has been shown to cooperate with muramyl dipeptide, a constituent of mycobacteria, for IL-6 induction in monocytic cell-lines (35). Similarly, it has been shown that IFN $\gamma$ is required for TNF $\alpha$ to induce IL-6 expression in human monocytic THP1 cells, whereas no significant induction was obtained with either cytokine alone (36). In A549 cell, IFN $\gamma$ did not increase the stimulatory effect of TNF $\alpha$ (data not shown).

Our results clearly indicate that the expression of IL-6 mRNA by A549 cells is inducible by AM secretory products. We cannot infer from these results obtained with a cell line that IL-6 gene expression by ATII cells is similarly regulated. This is a general comment for all results obtained with cell lines. However, our immunohistochemistry results demonstrate that immunoreactive IL-6 expression by alveolar epithelial cells can be raised in conditions where AM are activated, such as pulmonary fibrosis. Interstitial pulmonary fibrosis is characterized by a chronic inflammation of the alveolar space. AM are found in increased numbers and in an activated state both within the alveolar space and within the alveolar interstitium in the lungs of patients with interstitial pulmonary fibrosis (37). In vitro, activated human AM are potent producers of IL- 1 and TNF $\alpha$ (22). This suggests that in vivo activated AM could induce the expression of IL-6 by ATII cells through the release of stimulatory cytokines. Our results with rat ATII cells in primary culture support this hypothesis.

Alveolar epithelial cells have generally been considered as targets of inflammatory cells $(38 ; 39)$. Our results and available in vitro data suggest that alveolar epithelial cells may have an immunoregulatory role in the lung. ATII cells participate in the recruitement of inflammatory cells to the lungs through the generation of IL-8 (2), Monocyte Chemoattractant Protein-1 (4), complement (40), or leukotriene $B_{4}(41)$. Rat ATII cells have been shown in vitro to block the proliferation of lymphocytes without inhibiting their activation, in part through the secretion of soluble factor(s) (42). A549 cell supernatants have similar properties (21).

Crapo and co-workers (43) showed that in the human lung about $16 \%$ of alveolar cells are type II pneumocytes whereas $9 \%$ are alveolar macrophages. Similar results have been obtained in the rat (type II pneumocytes, $14 \%$; alveolar macrophages, $3 \%$ ) $(44,45)$. In addition, hyperplasia of alveolar epithelial cells is a common finding in lung diseases such as in the fibrotic lung (46). In these conditions it is highly probable that the ratio of alveolar epithelial cells over alveolar macrophages is increased. Altogether, these data suggest that IL- 6 secretion by ATII cells in vivo is quantitatively and biologically significant in the alveolar space. Moreover, it has been shown that alveolar macrophages and ATII cells are located predominantly at alveolar septal junctions, in close proximity to each other (47). This makes the potential for effective communication between these cell types and suggests that our in vitro results have an in vivo significance.

Cellular communication between immune and non-immune cells is likely an essential process in the initiation, maintenance, and resolution of the intra-alveolar inflammatory response. In this setting, it is worthnoting that IL-6 has been shown to exert some anti-inflammatory functions. In vitro, at pathologic concentrations, IL-6 inhibit $\mathrm{T}$ cell responses via the activation of macrophages that secrete TGF- $\beta$, a cytokine that impairs both $T$ cell and thymocyte proliferation responses (13). Moreover, IL-6 downregulates IL-1 $\beta$ and TNF $\alpha$ gene expression in human activated monocytes (48), modulate the synthesis of $\alpha 1$-antitrypsin in vitro in human mononuclear phagocytes (49), and induces a dysfunction of natural killer functions of lymphocytes (50). In vivo, in rats, intra-tracheal IL-6 partially inhibited the neutrophil alveolitis induced by intra-tracheal LPS (14).

In summary, the present study demonstrates that when adequately stimulated ATII cells produce IL- 6 which could participate in the complex cytokine network within the lung and play an important role in the local immune response of the alveolar space.

\section{Acknowledgments}

We are very grateful to Paul Soler (INSERM U82, Paris, France) for his helpful advice concerning immunohistochemistry. Expert technical assistance of Mrs. Marylène Proult, Evelyne Ulrich, and Christine Zedda is greatly acknowledged.

This work was supported by a grant from the Fondation pour la Recherche Medicale and l'Air Liquide company. Dr. Crestani is the recipient of a grant from the Fondation pour la Recherche Medicale.

\section{References}

1. Mason, J., and M. C. Williams. 1977. Type II alveolar cell. Defender of the alveolus. Am. Rev. Respir. Dis. 116:81-91.

2. Standiford, T. J., S. L. Kunkel, M. A. Basha, S. W. Chensue, J. P. I. Lynch, G. B. Toews, J. Westwick, and R. J. Strieter. 1990. Interleukin-8 gene expression by a pulmonary epithelial cell line. A model for cytokine networks in the lung. J. Clin. Invest. 86:1945-1953.

3. Hahon, N., and V. Castranova. 1989. Interferon production in rat type II pneumocytes and alveolar macrophages. Exp. Lung Res. 15:429-445.

4. Standiford, T. J., S. L. Kunkel, S. H. Phan, B. J. Rollins, and R. M. Strieter. 1991. Alveolar macrophage-derived cytokines induce monocyte chemoattractant protein-1 expression from human pulmonary type II-like epithelial cells. J. Biol. Chem. 266:9912-9918.

5. Khalil, N., R. N. O'Connor, H. W. Unruh, P. W. Warren, K. C. Flanders, A. Kemp, O. H. Bereznay, and A. H. Greenberg. 1991. Increased production and immunohistochemical localization of transforming growth factor beta in idiopathic pulmonary fibrosis. Am. J. Respir. Cell. Mol. Biol. 5:155-162.

6. Antoniades, H. N., M. A. Bravo, R. E. Avila, T. Galanopoulos, and J. Neville-Golden. 1990. Platelet-derived growth factor in idiopathic pulmonary fibrosis. J. Clin. Invest. 86:1055-1064.

7. Vignaud, J. M., M. Allam, N. Martinet, M. Pech, F. Plenat, and Y. Martinet. 1991. Presence of platelet-derived growth factor in normal and fibrotic lung is specifically associated with interstitial macrophages, while both interstitial macrophages and alveolar epithelial cells express the C-sis proto-oncogene. Am. J. Respir. Cell. Mol. Biol. 5:531-538.

8. Tazi, A., F. Bouchonnet, M. Grandsaigne, L. Boumsell, A. J. Hance, and P. Soler. 1993. Evidence that granulocyte-macrophage colony stimulating factor regulates the distribution and differentiated state of dendritic cells/Langerhans cells in human lung and lung cancers. J. Clin. Invest. 91:566-576. 
9. Krueger, J., A. Ray, I. Tamm, and P. B. Sehgal. 1991. Expression and function of interleukin-6 in epithelial cells. J. Cell. Biochem. 45:327-334.

10. Akira, S., T. Hirano, T. Taga, and T. Kishimoto. 1990. Biology of multifunctional cytokines: IL 6 and related molecules (IL 1 and TNF). FASEB (Fed. Am. Soc. Exp. Biol.) J. 4:2860-2867.

11. Elias, J. A., and V. Lentz. 1990. IL-1 and tumor necrosis factor synergistically stimulate fibroblast IL-6 production and stabilize IL-6 messenger RNA. $J$. Immunol. 145:161-166.

12. May, L. T., G. Torcia, F. Cozzolino, A. Ray, S. B. Tatter, U. Santhanam, P. B. Seghal, and D. Stern. 1989. Interleukin-6 gene expression in human endothelial cells, RNA start sites, multiple IL-6 proteins and inhibition of proliferation. Biochem. Biophys. Res. Commun. 159:991-998.

13. Zhou, D., A. Munster, and R. A. Winchurch. 1991. Pathologic concentrations of interleukin 6 inhibit $T$ cell responses via induction of activation of TGFB. FASEB (Fed. Am. Soc. Exp. Biol.) J. 5:2582-2585.

14. Ulich, T. R., S. Yin, K. Guo, E. S. Yi, D. Remick, and J. Del Castillo. 1991. Intratracheal injection of endotoxin and cytokines. II. Interleukin-6 and transforming growth factor beta inhibit acute inflammation. Am. J. Pathol. 138:1097-1101.

15. Jones, K. P., S. P. Reynolds, S. J. Capper, S. Kalinka, J. H. Edwards, and B. H. Davies. 1991. Measurement of interleukin-6 in bronchoalveolar lavage fluid by radioimmunoassay: differences between patients with interstitial lung disease and control subjects. Clin. Exp. Immunol. 83:30-34.

16. Grigg, J. M., and A. Barber. 1992. Increased levels of bronchoalveolar lavage fluid interleukin-6 in preterm ventilated infants after prolonged rupture of membranes. Am. Rev. Respir. Dis. 145:782-786.

17. Soliman, D. M., and H. I. I. Twigg. 1992. Cigarette smoking decreases bioactive interleukin-6 secretion by alveolar macrophages. Am. J. Physiol. (Lung Cell Mol Physiol 7). 236:L471-L478.

18. Crestani, B., C. Rolland, A. Petiet, N. Colas-Linhart, and M. Aubier. 1993. Cell surface carbohydrates modulate neutrophil adherence to alveolar type II cells in vitro. Am. J. Physiol. (Lung Cell Mol Physiol 8). 264:L391-L400.

19. Dobbs, L. G. 1990. Isolation and culture of alveolar type II cells. Am. J. Physiol. (Lung Cell Mol Physiol 2). 258:L134-L147.

20. Rothman, B. L., M. Merrow, A. Despins, T. Kennedy, and D. L. Kreutzer 1989. Effect of lipopolysaccharide on $\mathrm{C} 3$ and $\mathrm{C} 5$ production by human lung cells. J. Immunol. 143:196-202.

21. Paine, R., A. Chavis, D. Gaposchkin, P. Christensen, C. H. Mody, L. A Turka, and G. B. Toews. 1992. A factor secreted by a human pulmonary alveolar epithelial-like cell line blocks T-cell proliferation between $\mathrm{Gl}$ and $\mathrm{S}$ phase. Am. J. Respir. Cell. Mol. Biol. 6:658-666.

22. Boutten, A., M. Dehoux, M. Deschenes, J. D. Rouzeau, P. N. Bories, and G. Durand. 1992. Alpha 1-acid glycoprotein potentiates lipopolysaccharideinduced secretion of interleukin-6 and tumor necrosis factor-alpha by human monocytes and alveolar and peritoneal macrophages. Eur. J. Immunol. 22:26872695.

23. Aarden, L. A., E. R. De Groot, D. L. Schaap, and P. J. Landsorp. 1987. Production of hybridoma growth factor by human monocytes. Eur. J. Immunol. 17:1411-1416.

24. Mosmann, T. 1983. Rapid colorimetric assay for cellular growth and survival: application to proliferation and cytotoxicity assays. J. Immunol. Meth ods. 65:55-63.

25. Chomczynski, P., and N. Sacchi. 1987. Single-step method of RNA isolation by acid guanidium thiocyanate-phenol-chloroform extraction. Anal. Biochem $162: 156-159$

26. Hirano, T., K. Yasukawa, H. Harada, T. Taga, Y. Watanabe, T. Matsuda, S. Kashiwamura, K. Nakajima, K. Koyama, K. Iwamatsu, S. Tsunasawa, F. Sakiyama, H. Matsui, Y. Takahara, T. Taniguchi, and T. Kishimoto. 1986. Complementary DNA for a novel human interleukin (BSF-2) that induces B lymphocytes to produce immunoglobulin. Nature (Lond.) 324:73-76.

27. Chin, Y., J. Cai, and K. Johnson. 1990. Lymphocyte adhesion to cultured Peyer's patch high endothelial venule cells is mediated by organ-specific homing receptors and can be regulated by cytokines. J. Immunol. 145:3669-3677.

28. Edelson, J. D., J. M. Shannon, and R. J. Mason. 1988. Alkaline phospha- tase: a marker of type II cell differentiation. Am. Rev. Respir. Dis. 138:12681275.

29. Hirano, T., S. Akira, T. Taga, and T. Kishimoto. 1990. Biological and clinical aspects of interleukin 6. Immunol. Today. 11:443-449.

30. Ostinelli, J., M. Dehoux, M. Dechenes, N. Seta, J. L. Trouillet, C. Muller, and M. Aubier. 1991. Local production of cytokines in unilateral community acquired pneumonia. Am. Rev. Respir. Dis. 143:A392.

31. Hack, C. E., E. R. De Groot, R. J. F. Felt-Bersma, J. H. Nuijens, R. J. M. Strack Van Schijndel, A. J. M. Eerenberg-Belmer, L. G. Thijs, and L. A. Aarden. 1989. Increased plasma levels of interleukin-6 in sepsis. Blood. 74:1704-1710.

32. Kotloff, R. M., J. Little, and J. A. Elias. 1990. Human alveolar macrophage and blood monocyte interleukin-6 production. Am. J. Respir. Cell. Mol. Biol. 3:497-505.

33. Cromwell, O., Q. Hamid, C. J. Corrigan, J. Barkans, Q. Meng, and P. D. Collins. 1992. Expression and generation of interleukin-8, IL-6 and granulocytemacrophage colony-stimulating factor by bronchial epithelial cells and enhancement by IL-1 $\beta$ and tumor necrosis factor $\alpha$. Immunology. 77:330-337.

34. Humbert, M., O. Devergne, J. Cerrina, B. Rain, G. Simonneau, P. Dartevelle, P. Duroux, P. Galanaud, and D. Emilie. 1992. Activation of macrophages and cytotoxic cells during cytomegalovirus pneumonia complicating lung transplantations. Am. Rev. Respir. Dis. 145:1178-1184.

35. Sanceau, J., F. Beranger, C. Gaudelet, and J. Wietzerbin. 1990. Interferongamma is an essential cosignal for triggering IFN- $\beta 2 / \mathrm{BSF}-2 / \mathrm{IL}-6$ gene expression in human monocytic cell lines. Ann NY Acad. Sci. 557:130-139.

36. Sanceau, J., J. Wijdenes, M. Revel, and J. Wietzerbin. 1991. IL-6 and IL6 receptor modulation by IFN-gamma and tumor necrosis factor alpha in human monocytic cell line (THP-1). J. Immunol. 147:2630-2637.

37. Crouch, E. 1990. Pathobiology of pulmonary fibrosis. Am. J. Physiol. (Lung Cell Mol. Physiol. 3). 259:L159-L184.

38. Ayars, G. H., L. C. Altman, H. Rosen, and T. Doyle. 1984. The injurious effect of neutrophils on pneumocytes in vitro. Am. Rev. Respir. Dis. 130:964973.

39. Simon, R. H., P. D. Dehart, and R. F. Todd III. 1986. Neutrophil-induced injury of rat alveolar epithelial cells. J. Clin. Invest. 78:1375-1386.

40. Strunk, R. C., D. M. Eldlen, and R. J. Mason. 1988. Pulmonary alveolar type II epithelial cells synthesize and secrete proteins of the classical and alternative complement pathways. J. Clin. Invest. 81:1419-1426.

41. Cott, G. R., J. Y. Westcott, and N. F. Voelkel. 1990. Prostaglandin and leukotriene production by alveolar type II cells in vitro. Am. J. Physiol. (Lung Cell. Mol. Physiol. 2). 258:L179-L187.

42. Paine, R. I., C. H. Mody, A. Chavis, M. A. Spahr, L. A. Turka, and G. B. Toews. 1991. Alveolar epithelial cells block lymphocyte proliferation in vitro without inhibiting activation. Am. J. Respir. Cell. Mol. Biol. 5:221-229.

43. Crapo, J. D., B. E. Barry, P. Gehr, M. Bachofen, and E. R. Weibel. 1982. Cell number and cell characteristics of the normal human lung. Am. Rev. Respir. Dis. 125:332-337.

44. Crapo, J. D., B. E. Barry, H. A. Foscue, and J. S. Shelburne. 1980 Structural and biochemical changes in rat lungs occurring during exposures to lethal and adaptive doses of oxygen. Am. Rev. Respir. Dis. 122:123-145.

45. Haies, D. M., J. Gil, and E. R. Weibel. 1981. Morphometric study of rat lung cells. Am. Rev. Respir. Dis. 123:533-541.

46. Kawanami, O., V. J. Ferrans, and R. G. Crystal. 1982. Structure of alveolar epithelial cells in patients with fibrotic lung disorders. Lab. Invest. 46:39-53.

47. Parra, S. C., R. Burnette, H. P. Price, and T. Takaro. 1986. Zonal distribution of alveolar macrophages, type II pneumocytes, and alveolar septal connective tissue gaps in adult human lungs. Am. Rev. Respir. Dis. 133:908-912.

48. Schindler, R., J. Mancilla, S. Endres, R. Ghorbani, S. C. Clark, and C. A Dinarello. 1990. Correlations and interactions in the production of interleukin 6 (IL-6), IL-1, and tumor necrosis factor (TNF) in human blood mononuclear cells: IL-6 suppresses IL-1 and TNF. Blood. 75:40-47.

49. Perlmutter, D. H., L. T. May, and P. B. Sehgal. 1989. Interferon $\beta 2$ interleukin 6 modulates synthesis of $\alpha 1$-antitrypsin in human mononuclear phagocytes and in human hepatoma cells. J. Clin. Invest. 84:138-144.

50. Tanner, J., and G. Tosato. 1991. Impairment of natural killer functions by interleukin 6 increases lymphoblastoid cell tumorigenicity in athymic mice. $J$. Clin. Invest. 88:239-247. 